\title{
Assessment of Occupational Safety Practices Among Medical Laboratory Staff in Governmental Hospitals in Riyadh, Saudi Arabia
}

\author{
Abdulaziz J. Alshalani ${ }^{1,2}$ \\ ${ }^{1}$ Clinical Laboratory Medicine, AL Zulfi Hospital, Riyadh, Kingdom of Saudi Arabia \\ ${ }^{2}$ College of Public Health, Imam Abdulrahman Bin Faisal University, Dammam, \\ Kingdom of Saudi Arabia
}

\begin{abstract}
Khaled F. Salama (Corresponding Author)
Department of Environmental Health, College of Public Health, Imam Abdulrahman Bin Faisal University, Dammam, Kingdom of Saudi Arabia E-mail: Ksalama@iau.edu.sa
\end{abstract}

Received: June 28, 2019

Accepted: July 18, 2019

Published: July 21, 2019

doi:10.5296/jss.v5i1.14992

URL: https://doi.org/10.5296/jss.v5i1.14992

\begin{abstract}
Background: workers in laboratories are faced with many occupational risks at work and their health and safety may be severely jeopardized if adequate preventive protective measures are not taken. Objectives: to assess the level of occupational safety practices among laboratory staff in governmental hospitals in Riyadh, Saudi Arabia. Method: It was a cross sectional descriptive study among 107 laboratory staff, and 28 labs. Data was collected by a self-administered validated structured questionnaire and observation checklist, which were developed, and validated by us using guidelines on universal work precautions and based on previous studies. Results: Overall, there was a positive knowledge of, and attitude towards, occupational safety practices among medical laboratory staff. Nationality and age group were the only two variables that were significantly correlated with occupational safety practices. Almost of the occupational safety practices subscales were followed in the assessed subscales, except for certain parameters including mainly personal protective equipment's and electrical safety. Conclusion: Overall, a positive knowledge of, and attitude towards, occupational safety practices among medical laboratory staff was reported.
\end{abstract}

Keywords: Occupational Safety, Safety Practices, laboratory quality, Biological safety, 
laboratory accidents

\section{Introduction}

Generally, workers in laboratories are faced with many occupational risks at work and their health and safety may be severely risked if adequate preventive protective measures are not applied. These hazards can be physical, chemical and biological. ${ }^{(1,2)}$

Workers usually are faced with numerous occupational hazards and their health and safety may be severely risked if appropriate protective practices are not possessed ${ }^{(3-6)}$. The clinical laboratory staff are among those workers, and, they are exposed daily to various hazards and risks from human samples, infectious aerosols, spills, broken glass, cuts from sharp objects, needle stick injuries, chemical agents, centrifuge accidents and others ${ }^{(7,8)}$. For example, clinical laboratory staff is at increased risk of acquisition of viral (e.g. hepatitis B and C, corona virus, and HIV) and bacterial pathogens (e.g. TB), which can all be transmitted through percutaneous damage. $(9,10)$ Laboratory acquired tuberculosis infection was considered high among health care providers, including medical laboratory staff. ${ }^{(11,12)}$

Safety is defined as a method of preventing accidents or reducing personal injury or property damage that may be caused by an accident. Health and safety are key concern in any medical laboratory because of the potential risks in handling hazardous and infectious materials. These risks can be eliminated or minimized by promoting good laboratory practices as well as providing proper safety equipment. Although, there are legislations to govern health and safety aspects in the workplace, safety training is required to promote good safety practices and the situation varies greatly from one laboratory to another. ${ }^{(13.14)}$ Safety in laboratory is the responsibility of all the employees and employer.

Medical laboratories incorporate variety of occupational risks to laboratories health workers, as they continuously handle harmful biological agents and considered at higher risk of biological laboratory-associated infection. Several published reports provided evidences for the threat of the laboratory-associated infections of emerging and re-emerging diseases on the medical laboratory workers in general, and workers in labs in specific, are potentially exposed to an increased risk of acquiring wide range of infectious diseases including human immunodeficiency virus HIV, HBV and HCV. ${ }^{(15)}$

Medical laboratories universal precautions and good laboratory practices involve the use of protective barriers such as gloves, gowns, aprons, masks, or protective eyewear, which can reduce the risk of the infection. (16) The use of biological safety cabinets for aerosol-generating manipulations with biosafety level 2 practices and fit-tested respirators with N-95 rating should be routinely used and inspected. ${ }^{(17-24)}$

A study ${ }^{(25)}$ concluded fair to poor biosafety knowledge and practices among laboratory employee as well as lack of awareness regarding biosafety practices. Moreover, in another study conducted in one clinical laboratory in Shaqra University (Saudi Arabia) revealed that the workers in laboratories need to improve their knowledge, it is their responsibility for the adherence to biosafety policy, to use biosafety manual, personal protective equipment, biosafety containment level, and protection in their daily laboratory work. ${ }^{(26)}$ 
In study of Governmental Moderate and High Complexity Medical Labs, Saudi Arabia (2018), it was revealed that laboratory workers are exposed to biological hazards during collecting or processing biological materials, disinfecting, cleaning and transporting contaminated equipment, or working in contaminated areas. ${ }^{(27)}$

In a similar Ethiopian study showed that the respondents reported that there were poor safety regulations or standards in their laboratories, and higher risks of microbial, chemical and physical/mechanical hazards. ${ }^{(28)}$

Another study in Nigeria (2015) was found that the most common type of hazards in medical laboratories include; bacteria (80\%) for Biological hazards; handling un-labelled chemicals $(38.2 \%)$ for chemical hazards; and laboratory equipment's not periodically maintained (49.5\%) for Physical hazards, and not-wearing personal protective equipment's was statistically associated with exposure to hazards. ${ }^{(29)}$

In Jeddah, Saudi Arabia, a cross sectional design on 171 medical laboratory professionals working in governmental medical laboratories showed that there were significant differences in the level of knowledge among workers according to their job title, previous training and receiving biosafety manual; since the highest percentage of knowledgeable workers was recoded in consultants $(85.7 \%)$, followed by previously trained $(65.2 \%)$ and who received biosafety manual $(66.9 \%)$. Previous incidents were reported by more than one third $(36.3 \%)$ of the workers; its significant predictor was the positive biosafety practice, since it was much less frequent among health workers who have above average level of positive biosafety practices than those with below level $(60.9 \%$ vs $31.5 \%)$. This study came out with the conclusion that training on occupational health \& safety is a significant predictor of knowledge, practice, and incidents of the health workers in the labs ${ }^{(30)}$

Another study conducted in clinical laboratories in Nigeria revealed that a strict safety system of work was needed for adherence to biosafety policies and practices as the level of biosafety performance was not impressive (31) Similarly, biosafety precautions adopted by the laboratory workers in Sudan were below the standards with reference to biosafety awareness and practices. ${ }^{(32)}$

In Pakistan, lack of awareness of biosafety measures and practices among clinical laboratory personnel and inadequate supply of biosafety equipment are the main reasons for poor biosafety performance ${ }^{\text {(33) }}$ Additionally, in a study in Karachi revealed that no biological safety cabinets (BSCs) were available in many biosafety level 2 (BSL-2) laboratories. Negligence with respect to all major practices, personal protective equipment (PPE), engineering controls, and risk assessment was observed. Moreover, there was no system of Laboratory associated infections (LAI) reporting in place, and knowledge and training of biosecurity and biosafety were below the standards. ${ }^{(34)}$

A study in AL Madinah city, Saudi Arabia revealed showed that about $68 \%$ of the workers were trained in laboratory safety, the majority $(>80 \%)$ followed guidelines for disposing medical wastes, decontamination of sample spills, and use of protective lab coats, and gloves. However, $24.2 \%$ of the participants used to eat, drink or use gum. almost $18 \%$ reported that they continued working with a finger cut, whereas only $67 \%$ reported that they used to recap 
needles after blood withdrawal. ${ }^{(35)}$

In Philippines high institutions ${ }^{(36)}$, and in others study ${ }^{(37)}$, absence of safety data sheets (SDS) of chemicals and apparatuses, absence of complete personal protective equipment (PPE) absence of safety cabinets for chemicals storage were recorded respectively. The main goal of the study was to assess the level of occupational safety practices among laboratory staff in governmental hospitals in Riyadh, Saudi Arabia.

\section{Material and Methods}

\subsection{Study Setting and Target Population}

\subsubsection{Study Design}

This was a cross sectional survey study conducted among three randomly selected governmental hospitals laboratories in Riyadh (AL Zulfi hospital, King Khaled hospital Al Majmaa and Hotat Souder), Saudi Arabia.

This study was conducted from January 2019 to March 2019 in Saudi Arabia. In this study, the survey analyzed Chemical biological and biosafety performance among selected laboratories in Riyadh hospitals cross sectional survey study conducted among three randomly selected governmental hospitals laboratories in Riyadh

The study was conducted in three hospitals in Riyadh AL Zulfi hospital, King Khaled hospital Al Majmaa and Hotat Souder) Moreover, a total number of 28 medical laboratories with different specialties were assessed regarding occupational safety practices using an observation checklist.

Sample size and sampling technique:

Sample size was calculated by WHO (World Health Organization) sample size calculator that total population size is 120 , with $95 \%$ confidence interval, margin of error is $5 \%$ for an expected prevalence of hazardous events of biological laboratory associated infection is $36 \%$ from previous study. We should 90 laboratory staff required for this study.

This research is a cross-sectional descriptive study in the form of a survey to analyze practices and safety performance through a structured questionnaire and checklist. The Questionnaire used for data collection in the current study was a Self-administered validated structured questionnaire ${ }^{(53)}$ and observation checklist, which were developed, and pretested by us by using guidelines on universal work precautions, based on previous studies. ${ }^{\text {(38-40) }}$

The questionnaire was prepared Information sought included socio-demographic Characteristics such as age, sex, marital status and duration of working experience.

The survey inspection checklist was adopted from the "Prudent Practices in the Laboratory: Handling and Management of chemical hazards". 40 survey inspection checklist used in this study comprised of eleven safety elements; general work environment; lab safety documents; emergency planning; emergency planning equipment; personal protective equipment; chemical storage \& chemical labeling; fume hood and chemical handling; compressed gas; electrical safety; waste and hazardous waste management and safety training / awareness. 
each safety element has several safety items ranging from seven to twelve. Three types of questions were asked categorically during the survey such as "Yes", "No" and not applicable (NA) if the safety item does not apply.

\subsection{Data Source and Population}

Inclusion criteria: All laboratory staff (Technicians and medical doctor) were included in the study.

Exclusion criteria: Trainee, volunteers, interns and portal cleaners were excluded from the study.

Ethical consideration: Data gathering, and analysis was done following the approval of the Institutional Ethical and Review Board (IRB) of Imam Abdulrahman Bin Faisal university (IAU). (IRB-PGS-2019-03-195)

Statistical analysis: All the collected data was descriptive, and the test significance was done through t-test and analyzed by Statistical Package for Social Sciences (SPSS) software version 24.

\section{Results}

The total number of the current study participants was 107 laboratory staff from three different governmental hospitals in Riyadh, Saudi Arabia. More than two thirds $(68.22 \%)$ of the respondents were males, and vast majority (93.45\%) of them were Saudi. More than half $(55.14 \%)$ of the participants have B. SC degree, and the largest proportion (40/107) have an experience of $<5$ years.

The mean score and median for the whole questionnaire items were calculated by participants baseline characteristics. The results here highlighted that there was a statistically significant difference in the score of occupational safety practices among medical laboratory staff by nationality and age group. A high statistically significant positive mean score was shown from non- Saudi at $103.4286( \pm 5.62308)$ compared to Saudi at $92.1600( \pm 13.53911)$, with a P value of 0.012 . For the age, there was a positive linear correlation between the participants age group and the mean score of the questionnaire at 88.8571, 90.1429, 94.6923, and 98.6400 for the age groups $<28 \mathrm{y}, 29-32,33-35$, and $\geq 36$ years, respectively.

The gender, educational level and years of experience did not show any significant correlation the occupational safety practices among medical laboratory staff, since all $\mathrm{P}$ values were $>0.05$. The mean score of females was higher than that of males of 94.5294 and 92.1370 , respectively. The results revealed that positive score increased by increasing both the years of experience as well as the educational level. Where participants whose experience was $>10$ years scored at 95.818 , followed by 92.679 , and 90.05 for those with 5-10 years and $<5$ years of experience, respectively. Similarly, those with master \& PHD had the highest score at 95.4762. However, gender, educational level and years of experience did not show any significant correlation with the occupational safety practices among medical laboratory staff, since all $\mathrm{P}$ values were $>0.05$. As shown in Table 1 . 
Table 1. Socio-demographic characteristic among participants

\begin{tabular}{|c|c|c|c|c|c|c|c|}
\hline & $\mathrm{N}$ & Mean & Std. Deviation & Median & Minimum & Maximum & P-value \\
\hline Total cases & 107 & 92.897 & 13.447 & 93.0 & 46.0 & 115.0 & \\
\hline \multicolumn{8}{|l|}{ Gender } \\
\hline Male & 73 & 92.1370 & 13.60179 & 92.0 & 46.0 & 115.0 & 0.262 \\
\hline Female & 34 & 94.5294 & 13.15925 & 96.0 & 55.00 & 115.0 & \\
\hline \multicolumn{8}{|l|}{ Nationality } \\
\hline Saudi & 100 & 92.1600 & 13.53911 & 92.0 & 46.00 & 115.00 & 0.012 \\
\hline Non-Saudi & 7 & 103.428 & 5.62308 & 102.0 & 97.00 & 114.00 & \\
\hline \multicolumn{8}{|l|}{ Age groups } \\
\hline Low -28 y & 28 & 88.8571 & 13.94623 & 91.0 & 55.00 & 115.00 & \\
\hline $29-32$ & 28 & 90.1429 & 14.26914 & 91.5 & 46.00 & 115.00 & 0.031 \\
\hline $33-35 y$ & 26 & 94.6923 & 12.64205 & 92.5 & 68.00 & 115.00 & \\
\hline $36 y+$ & 25 & 98.6400 & 10.88914 & 102 & 78.00 & 115.00 & \\
\hline \multicolumn{8}{|c|}{ Years of experience } \\
\hline$<5 \mathrm{y}$ & 40 & 90.05 & 14.1057 & 91.0 & 55.0 & 115.0 & \\
\hline $5-10 y$ & 28 & 92.679 & 14.6946 & 92.0 & 46.0 & 115.0 & 0.113 \\
\hline$>10 y$ & 33 & 95.818 & 11.5311 & 100.0 & 67.0 & 114.0 & \\
\hline \multicolumn{8}{|c|}{ Education levels } \\
\hline Diploma & 27 & 93.0370 & 15.53527 & 96.0 & 55.00 & 115.00 & \\
\hline B.SC & 59 & 91.9153 & 13.68902 & 92.0 & 46.00 & 115.00 & 0.519 \\
\hline Master + PHD & 21 & 95.4762 & 9.55834 & 93.0 & 80.00 & 114.00 & \\
\hline
\end{tabular}

The mean $( \pm \mathrm{SD})$, as well as the frequency (percentage $\%)$ of each of the questionnaire items was calculated. Overall, it was noted that there was a positive occupational safety practices among medical laboratory staff in governmental hospitals in Riyadh, Saudi Arabia, since all the mean score were ranging from 3.22 to 4.57 , values that are going more towards the positive side 
The results showed that the highest mean score was for the point "I always take care of the laboratory and keep it clean and tidy" with a mean score of $4.57( \pm 0.601)$, indicating that the majority of the participants $(60.7 \%)$ were strongly agree on this point. This was followed by the point "I know precautions to be taken in case of spills and splashes of chemicals", for which $53.3 \%$ replied with strongly agree, and $41.1 \%$ agree. On the other hand, the lowest scored item in the questionnaire was "I wash my hands before putting on gloves", with a mean of $3.22( \pm 1.456)$, where the highest percentage $(39.3 \%)$ disagreed to this point. The second lower scored item was "I know how to use bucket of sand in case of a fire", for which $41.1 \%$ agree, $256.2 \%$ disagree, $19.6 \%$ strongly agree, and $14 \%$ strongly disagree.

More than $90 \%$ of the study participants know which emergency kits must be in a laboratory for using in case of an emergency, and more than $93 \%$ know how to use water system in laboratory.

Almost $23 \%$ of the laboratory staff in the current study do not know how to store chemicals which need to have special conditions, moreover, more than $43 \%$ were leaving the laboratory before checking all electrical devices. As shown in Table 2-4.

Table 2. Questionnaire surveyed data among medical laboratory workers (Q1-Q8)

\begin{tabular}{|c|c|c|c|c|c|c|}
\hline & $\begin{array}{l}\text { Strongly } \\
\text { Disagree }\end{array}$ & Disagree & Agree & $\begin{array}{l}\text { Strongly } \\
\text { Agree }\end{array}$ & Mean & SD \\
\hline $\begin{array}{l}\text { I always take care the laboratory and keep it clean } \\
\text { and tidy }\end{array}$ & --- & $\begin{array}{c}2 \\
(1.9)\end{array}$ & $\begin{array}{c}40 \\
(37.4)\end{array}$ & $\begin{array}{c}65 \\
(60.7)\end{array}$ & 4.57 & 0.601 \\
\hline $\begin{array}{l}\text { I know precautions to be taken in case of spills and } \\
\text { splashes of chemicals }\end{array}$ & $\begin{array}{c}1 \\
(0.9 \%)\end{array}$ & $\begin{array}{c}5 \\
(4.7 \%)\end{array}$ & $\begin{array}{c}44 \\
(41.1 \%)\end{array}$ & $\begin{array}{c}57 \\
(53.3 \%)\end{array}$ & 4.41 & 0.8 \\
\hline $\begin{array}{l}\text { I know which emergency kits must be in a } \\
\text { laboratory for using in case of an emergency }\end{array}$ & $\begin{array}{c}2 \\
(1.9 \%)\end{array}$ & $\begin{array}{c}8 \\
(7.5 \%)\end{array}$ & $\begin{array}{c}43 \\
(40.2 \%)\end{array}$ & $\begin{array}{c}54 \\
(50.5 \%)\end{array}$ & 4.30 & 0.944 \\
\hline I know the phone numbers to call in an emergency & $\begin{array}{c}2 \\
(1.9 \%)\end{array}$ & $\begin{array}{c}10 \\
(9.3 \%)\end{array}$ & $\begin{array}{c}42 \\
(39.3 \%)\end{array}$ & $\begin{array}{c}53 \\
(49.5 \%)\end{array}$ & 4.25 & 0.991 \\
\hline $\begin{array}{l}\text { I know how the standards of an ideal laboratory } \\
\text { should be }\end{array}$ & $\begin{array}{c}1 \\
(0.9 \%)\end{array}$ & $\begin{array}{c}9 \\
(8.4 \%)\end{array}$ & $\begin{array}{c}52 \\
(48.6 \%)\end{array}$ & $\begin{array}{c}45 \\
(42.1 \%)\end{array}$ & 4.22 & 0.893 \\
\hline $\begin{array}{l}\text { I know how to use the ventilation and exhaust } \\
\text { system }\end{array}$ & $\begin{array}{c}11 \\
(10.3 \%)\end{array}$ & $\begin{array}{c}17 \\
(15.9 \%)\end{array}$ & $\begin{array}{c}54 \\
(50.5 \%)\end{array}$ & $\begin{array}{c}25 \\
(23.4 \%)\end{array}$ & 3.61 & 1.287 \\
\hline I know how to use water system in laboratory & $\begin{array}{c}4 \\
(3.7 \%)\end{array}$ & $\begin{array}{c}3 \\
(2.8 \%)\end{array}$ & $\begin{array}{c}61 \\
(57.0 \%)\end{array}$ & $\begin{array}{c}39 \\
(36.4 \%)\end{array}$ & 4.20 & 0.884 \\
\hline I know how to use gas installations & $\begin{array}{c}14 \\
(13.1 \%)\end{array}$ & $\begin{array}{c}21 \\
(19.6 \%)\end{array}$ & $\begin{array}{c}49 \\
(45.8 \%)\end{array}$ & $\begin{array}{c}23 \\
(21.5 \%)\end{array}$ & 3.43 & 1.367 \\
\hline
\end{tabular}


Table 3. Questionnaire surveyed data among medical laboratory workers (Q9-Q18)

\begin{tabular}{|c|c|c|c|c|c|c|}
\hline & $\begin{array}{l}\text { Strongly } \\
\text { Disagree }\end{array}$ & Disagree & Agree & $\begin{array}{c}\text { Strongly } \\
\text { Agree }\end{array}$ & Mean & SD \\
\hline I know how to use fire extinguisher in case of a fire & 0 & $\begin{array}{c}9 \\
(8.4 \%)\end{array}$ & $\begin{array}{c}48 \\
(44.9 \%)\end{array}$ & $\begin{array}{c}50 \\
(46.7 \%)\end{array}$ & 4.30 & 0.849 \\
\hline I know how to use bucket of sand in case of a fire & $\begin{array}{c}15 \\
(14.0 \%)\end{array}$ & $\begin{array}{c}27 \\
(25.2 \%)\end{array}$ & $\begin{array}{c}44 \\
(41.1 \%)\end{array}$ & $\begin{array}{c}21 \\
(19.6 \%)\end{array}$ & 3.27 & 1.398 \\
\hline I know how to use fire blanket in case of a fire & $\begin{array}{c}5 \\
(4.7 \%)\end{array}$ & $\begin{array}{c}8 \\
(7.5 \%)\end{array}$ & $\begin{array}{c}52 \\
(48.6 \%)\end{array}$ & $\begin{array}{c}42 \\
(39.3 \%)\end{array}$ & 4.10 & 1.055 \\
\hline I know the needs and uses of an emergency exit plan & $\begin{array}{c}2 \\
(1.9 \%)\end{array}$ & $\begin{array}{c}6 \\
(5.6 \%)\end{array}$ & $\begin{array}{c}46 \\
(43.0 \%)\end{array}$ & $\begin{array}{c}53 \\
(49.5 \%)\end{array}$ & 4.33 & 0.888 \\
\hline I know how to use first aid kits in laboratory & $\begin{array}{c}4 \\
(3.7 \%)\end{array}$ & $\begin{array}{c}4 \\
(3.7 \%)\end{array}$ & $\begin{array}{c}49 \\
(45.8 \%)\end{array}$ & $\begin{array}{c}50 \\
(46.7 \%)\end{array}$ & 4.28 & 0.940 \\
\hline I know how to store and keep solid chemicals & $\begin{array}{c}4 \\
(3.7 \%)\end{array}$ & $\begin{array}{c}14 \\
(13.1 \%)\end{array}$ & $\begin{array}{c}51 \\
(47.7 \%)\end{array}$ & $\begin{array}{c}38 \\
(35.5 \%)\end{array}$ & 3.98 & 1.107 \\
\hline I know how to store and keep the liquid chemicals & $\begin{array}{c}3 \\
(2.8 \%)\end{array}$ & $\begin{array}{c}16 \\
(15.0 \%)\end{array}$ & $\begin{array}{c}52 \\
(48.6 \%)\end{array}$ & $\begin{array}{c}36 \\
(33.6 \%)\end{array}$ & 3.95 & 1.094 \\
\hline $\begin{array}{l}\text { I know how to store chemicals which need to have } \\
\text { special conditions }\end{array}$ & $\begin{array}{c}4 \\
(3.7 \%)\end{array}$ & $\begin{array}{c}21 \\
(19.6 \%)\end{array}$ & $\begin{array}{c}40 \\
(37.4 \%)\end{array}$ & $\begin{array}{c}42 \\
(39.3 \%)\end{array}$ & 3.89 & 1.231 \\
\hline $\begin{array}{l}\text { I work with an inventory which has the } \\
\text { identifications of all chemicals in the laboratory }\end{array}$ & $\begin{array}{c}2 \\
(1.9 \%)\end{array}$ & $\begin{array}{c}19 \\
(17.8 \%)\end{array}$ & $\begin{array}{c}54 \\
(50.5 \%)\end{array}$ & $\begin{array}{c}32 \\
(29.9 \%)\end{array}$ & 3.89 & 1.084 \\
\hline $\begin{array}{l}\text { I always wear lab apron during the activities in } \\
\text { laboratory }\end{array}$ & $\begin{array}{c}2 \\
(1.9 \%)\end{array}$ & $\begin{array}{c}9 \\
(8.4 \%)\end{array}$ & $\begin{array}{c}57 \\
(53.3 \%)\end{array}$ & $\begin{array}{c}39 \\
(36.4 \%)\end{array}$ & 4.14 & 0.926 \\
\hline
\end{tabular}

Table 4. Questionnaire surveyed data among medical laboratory workers (Q19-Q23)

\begin{tabular}{|c|c|c|c|c|c|c|}
\hline & $\begin{array}{l}\text { Strongly } \\
\text { Disagree }\end{array}$ & Disagree & Agree & $\begin{array}{l}\text { Strongly } \\
\text { Agree }\end{array}$ & Mean & $\mathrm{SD}$ \\
\hline I know what should be done in case of sharp injury & $\begin{array}{c}2 \\
(1.9 \%)\end{array}$ & $\begin{array}{c}6 \\
(5.6 \%)\end{array}$ & $\begin{array}{c}43 \\
(40.2 \%)\end{array}$ & $\begin{array}{c}56 \\
(52.3 \%)\end{array}$ & 4.36 & 0.893 \\
\hline $\begin{array}{l}\text { I know what should be done if any chemicals splash to the } \\
\text { eyes }\end{array}$ & $\begin{array}{c}1 \\
(0.9 \%)\end{array}$ & $\begin{array}{c}9 \\
(8.4 \%)\end{array}$ & $\begin{array}{c}52 \\
(48.6 \%)\end{array}$ & $\begin{array}{c}45 \\
(42.1 \%)\end{array}$ & 4.22 & 0.893 \\
\hline
\end{tabular}


I never leave the laboratory before checking all electrical devices

I wash my hands Before putting on gloves

I wash my hands After removing gloves

8
$(7.5 \%)$

39
$(36.4 \%)$

28

$(26.2 \%)$

32

$3.35 \quad 1.422$

$42 \quad 24 \quad 31$

(39.3\%)

$(22.4 \%)$

$(29.0 \%)$

$3.22 \quad 1.456$

$\begin{array}{ccccc}3 & 23 & 79 & & \\ (2.8 \%) & (21.5 \%) & (73.8 \%) & & 0.795\end{array}$

For the general laboratory safety subscale, vast majority of the labs were scored as "yes" to most of the general laboratory safety items except for few items for which the answers were mainly "No". Those items that were mainly scored as no include mainly "Is there a contingency waste management plan in the circumstance that waste removal companies refuse to transport specific medical waste?" at $100 \%$, and "do staff refrain from using cellphone and bringing personal items (purses, backpacks, books, magazines etc.) into the laboratory?" at $89.3 \%$. Table 5 .

Table 5. Observational checklist surveyed data of general laboratory safety

\begin{tabular}{|c|c|c|c|}
\hline General Laboratory safety & YES & NO & I don't Know \\
\hline $\begin{array}{l}\text { Are staff and/or students adequately trained and supervised to ensure safe } \\
\text { work procedures? }\end{array}$ & $28(100 \%)$ & $\mathbf{0 \%}$ & $\mathbf{0 \%}$ \\
\hline Are new and young workers appropriately supervised and informed? & $28(100 \%)$ & $\mathbf{0 \%}$ & $\mathbf{0 \%}$ \\
\hline $\begin{array}{l}\text { Are hazard warning signs posted on the door indicating any hazards that } \\
\text { may be present (e.g. biological, radioactive materials, or high noise } \\
\text { emitting equipment)? }\end{array}$ & $28(100 \%)$ & $\mathbf{0 \%}$ & $\mathbf{0 \%}$ \\
\hline $\begin{array}{l}\text { Is there a door that can be closed to keep visitors out of the lab while work } \\
\text { with the dangerous substances or biological agents is in progress? }\end{array}$ & $28(100 \%)$ & $\mathbf{0 \%}$ & $\mathbf{0 \%}$ \\
\hline Where required, is access to the lab restricted to authorized persons only? & $28(100 \%)$ & $\mathbf{0 \%}$ & $\mathbf{0 \%}$ \\
\hline $\begin{array}{l}\text { Are storage areas (rooms, refrigerators, freezers, cupboards) where } \\
\text { infectious and/or toxic materials are kept labelled accordingly? }\end{array}$ & $28(100 \%)$ & $\mathbf{0 \%}$ & $\mathbf{0 \%}$ \\
\hline Are all chemicals clearly labelled, including hazard symbols? & $28(100 \%)$ & $\mathbf{0 \%}$ & $\mathbf{0 \%}$ \\
\hline $\begin{array}{l}\text { Are all biomaterials clearly labelled, including the hazard symbol where } \\
\text { appropriate? }\end{array}$ & $28(100 \%)$ & $\mathbf{0 \%}$ & $\mathbf{0 \%}$ \\
\hline Are glass bottles stored where they cannot be knocked or kicked over? & $28(100 \%)$ & $\mathbf{0 \%}$ & $\mathbf{0 \%}$ \\
\hline
\end{tabular}


Are all pressure vessels (including pressurized liquid nitrogen Dewar's) periodically inspected and certified?

11

(39.3\%)

Is the safe working pressure clearly marked on all pressure vessels?

Are all pressurized gas cylinders properly secured by restraining chains, bench clamps or similar?

Are gas cylinders sited away from doors or escape routes?

Are there written procedures to deal with specimen receiving, leaking containers, and visible contamination of the outside of containers?

Are personal precautions such has hand washing, the use of splash guards at Workstations, and no sniffing of culture plates strictly enforced?

Are all surfaces in the laboratory regularly disinfected with an intermediate level Disinfectant each day of work?

Do staff refrain from touching eyes, nose, mouth and lips while in the Laboratory.

Is prohibition of the storage of food or drink in the laboratory enforced?

Do staff refrain from using cellphone and bringing personal items (purses, backpacks, books, magazines etc.) into the laboratory?

Are procedures available for safely dispensing blood and blood products?

Is there a contingency waste management plan in the circumstance that waste removal companies refuse to transport specific medical waste?
$27(96.4 \%)$

$28(100 \%)$

$19(67.9 \%)$

$28(100 \%)$

$27(96.4 \%)$

(3.6\%)

13

(46.4\%)

$1(3.6 \%)$

$14(50.0 \%)$

2

(7.1\%)

25

(89.3 \%)

10

(35.7\%)

$18(64.3 \%)$

28

0\%

(100\%)
0\%

0\%

0\%

$\mathbf{0 \%}$

$\mathbf{0 \%}$

0\%

$\mathbf{0 \%}$

0\%

$\mathbf{0 \%}$

0\%

For the general work environment, the results revealed that there was a lack of safety in the general work environment, especially for the points "Illumination is adequate in work area", and "Lab layout is proper" as $92.9 \%$ of the assessed labs scored as "No" for each of the two points. Similarly, there was a shortage in the lab safety documents, where $92.9 \%$ of the assessed labs lacking the occurrence variant report reporting systems, and almost 38\% of them lacking the other assessed items. Table $6 \& 7$.

Table 6. Observational checklist surveyed data general work environment (GWE) 
$\mathbf{0 \%}$

Table 7. Observational checklist surveyed data of Lab Safety Documents

\begin{tabular}{lcc}
\hline Lab Safety Documents & YES & NO \\
\hline $\begin{array}{l}\text { Updated Lab safety Manual, Chemical hygiene, Emergency action } \\
\text { plan and Spill response guide is available }\end{array}$ & $\mathbf{1 8}(64.3 \%)$ & $\mathbf{1 0}(\mathbf{3 5 . 7} \%)$ \\
Lab accidents and injuries records are maintained & $\mathbf{1 8}(\mathbf{6 4 . 3} \%)$ & $\mathbf{1 0}(\mathbf{3 5 . 7} \%)$ \\
Safety data Sheets are available (SDS) & $\mathbf{1 8}(\mathbf{6 4 . 3} \%)$ & $\mathbf{1 0}(\mathbf{3 5 . 7} \%)$ \\
Updated Lab chemicals inventory are available & $\mathbf{1 8}(\mathbf{6 4 . 3} \%)$ & $\mathbf{1 0}(\mathbf{3 5 . 7} \%)$ \\
Occurrence variant report reporting systems & $\mathbf{2 ( 7 . 1 \% )}$ & $\mathbf{2 6}(\mathbf{9 2 . 9} \%)$ \\
The Laboratory is accredited & $\mathbf{1 8}(\mathbf{6 4 . 3} \%)$ & $\mathbf{1 0}(\mathbf{3 5 . 7} \%)$ \\
\hline
\end{tabular}

For the emergency planning, it was found that all the assessed labs have all the upcoming emergency planning: exits are illuminated and unobstructed, emergency exits are unobstructed, posted, Emergency contact numbers and Evacuation Routes posted, and emergency equipment labeled with highly visible signs. For the emergency planning equipment, the labs have most of the equipment, except for "Fire alarm pull stations unobstructed" and "Fire detectors, fire alarms and fire sprinkler are functional" that are lacked in $96.4 \%$, and $92.9 \%$ of the labs, respectively. Table 8 .

Additionally, fire detectors, fire alarms and fire sprinkler were not inspected regularly in $42.9 \%$ of the inspection of emergency planning equipment such as emergency shower/eyewash, fire detectors, fire alarms and fire sprinkler was the labs, also poor. EPE such as fire extinguishers had positive results as compared to other safety items of this safety element. According to the Saudi building codes employees assigned fire-fighting duties shall 
be trained to know the locations and proper use of portable fire extinguishers or other manual fire-fighting equipment and the protective clothing or equipment required for its safe and proper use.

Table 8. Observational checklist surveyed data of emergency planning (EP)

\begin{tabular}{|c|c|c|}
\hline Emergency Planning (EP) & YES & NO \\
\hline Exits are illuminated and unobstructed & $28(100 \%)$ & $\mathbf{0 \%}$ \\
\hline $\begin{array}{l}\text { Emergency exits are unobstructed, posted, Emergency contact numbers and } \\
\text { Evacuation Routes posted }\end{array}$ & $28(100 \%)$ & $\mathbf{0 \%}$ \\
\hline Emergency equipment labeled with highly visible signs & $28(100 \%)$ & $0 \%$ \\
\hline Emergency shower/ Eyewash is unobstructed & $28(100 \%)$ & $\mathbf{0 \%}$ \\
\hline Eyewash unit and safety shower inspection up to date (twice in a year) & $28(100 \%)$ & $\mathbf{0 \%}$ \\
\hline First Aid kit is available and visible & $28(100 \%)$ & $\mathbf{0 \%}$ \\
\hline Spill kit/ cleanup materials provided and adequate & $28(100 \%)$ & $0 \%$ \\
\hline Fire extinguishers mounted and unobstructed & $28(100 \%)$ & $\mathbf{0 \%}$ \\
\hline Fire extinguishers fully charged with tamper indicator in place & $28(100 \%)$ & $0 \%$ \\
\hline Fire extinguisher inspection up to date (6 months) & $27(96.4 \%)$ & $1(3.6 \%)$ \\
\hline Fire alarm pull stations unobstructed & $1(3.6 \%)$ & $27(96.4 \%)$ \\
\hline Fire detectors, fire alarms and fire sprinkler are functional & $0 \%$ & $26(92.9 \%)$ \\
\hline Fire detectors, fire alarms and fire sprinkler inspected regularly & $1(3.6 \%)$ & $12(42.9 \%)$ \\
\hline
\end{tabular}

The results of the current study revealed a high lack of personal protective equipment, especially, Hearing protection ones which are not available in all labs. In addition, hand protection gloves were not available when dealing with chemicals, hot objects, and sharp objects at $96.4 \%$ of the labs. Moreover, $92.9 \%$ of the labs lacking the appropriate clothing to the hazards posed in the laboratory, appropriate shoes to the hazard and eye and face protection when dealing with chemicals. Table 9.

Table 9. Observational checklist surveyed data of personal protective equipment (PPE)

\begin{tabular}{lcc}
\hline Personal Protective Equipment (PPEs) & YES & NO \\
\hline Eye and face protection is available when dealing with chemicals. & $2(7.1 \%)$ & $26(92.9 \%)$ \\
\hline
\end{tabular}


Hand protection (gloves) is available when dealing with chemicals, hot objects, sharp objects, etc.

For the electrical safety, there were clear problems in the labs, particularly, guards/covers were not in place for electrophoresis devices, and high voltage equipment's were not labeled appropriately. This is an indication of poor safety performance of the surveyed labs in terms of safety Labelling. Lab staff were found to be unaware of the use of ground fault circuit interrupters (GFCI) or residual current device (RCD) used in wet areas. Table (10).

Table 10. Observational checklist surveyed data of electrical safety (ES)

\begin{tabular}{lcc}
\hline Electrical Safety (ES) & YES & NO \\
\hline Flexible cords in good condition & $28(100 \%)$ & $0 \%$ \\
Cover plates in place for outlets and switches & $28(100 \%)$ & $0 \%$ \\
Circuit breaker panels are unobstructed & $28(100 \%)$ & $18(64.3 \%)$ \\
Multi plug adapters have overload protection & $10(35.7 \%)$ & $10(35.7 \%)$ \\
No extension cords used & $18(64.3 \%)$ & $27(96.4 \%)$ \\
Ground fault circuit interrupters (GFCI) or Residual Current Device & $1(3.6 \%)$ & $26(92.9 \%)$ \\
Guards/covers in place for electrophoresis devices & $2(7.1 \%)$ & $26(92.9 \%)$ \\
\hline
\end{tabular}

Generally, a good management of waste and hazardous waste was clear from the current study results, except for waste containers were not always sealed in $96.4 \%$, and not all hazardous chemical waste were arranged to be picked up by safety department by $92.9 \%$, of the labs. Table 11. 
Table 11. Observational checklist surveyed data of Waste and hazardous waste management (WHWM)

\begin{tabular}{lcc}
\hline Waste and Hazardous Waste Management (WHWM) & YES & NO \\
\hline Proper management of hazardous materials and waste & $28(100 \%)$ & $0 \%$ \\
Liquid chemical waste is not disposed of in the sink & $28(100 \%)$ & $27(96.4 \%)$ \\
Waste containers are always sealed. & $1(3.6 \%)$ & $0 \%$ \\
Waste containers labeled with the contents, "Hazardous Waste" & $28(100 \%)$ & $0 \%$ \\
Containers are compatible with waste & $28(100 \%)$ & $0 \%$ \\
Separate disposal containers available for broken glass & $28(100 \%)$ & $0 \%$ \\
Waste is segregated and stored appropriately away from drains & $28(100 \%)$ \\
All hazardous chemical waste is arranged to be picked up by safety department & $2(7.1 \%)$ & $26(92.9 \%)$ \\
\hline
\end{tabular}

Unfortunately, more than one third of the assessed labs workers did not attend appropriate safety training or laboratory orientation (35.7\% and 39.3\%, respectively). Table (12).

Table 12. Observational checklist surveyed data of safety training/ awareness (STA)

\begin{tabular}{lcr}
\hline Safety Training/ Awareness (STA) & YES & NO \\
\hline Workers have attended appropriate safety training & $18(64.3 \%)$ & $10(35.7 \%)$ \\
Workers have attended a laboratory orientation & $17(60.7 \%)$ & $11(39.3 \%)$ \\
Training records is documented & $18(64.3 \%)$ & $10(35.7 \%)$ \\
\hline
\end{tabular}

Safety items such as safety training and its documentation, information about the chemical hygiene plan, how to clean chemical spill, and information about assigned assembly area had poor responses. This can be attributed to the limited laboratory safety knowledge of the laboratory staff. Table (13).

Table 13. Observational checklist surveyed data of Laboratory personnel know

\begin{tabular}{lcc}
\hline Laboratory personnel know... & YES & NO \\
\hline What to do in the event of an emergency, such as fire, injury, including evacuation routes? & $28(100 \%)$ & $0 \%$ \\
How to clean up chemical spills? & $28(100 \%)$ & $0 \%$ \\
\hline
\end{tabular}


Where is the location/contents of the Chemical Hygiene Plan?

Who is the Chemical Hygiene Officer and Safety Manager for the department?

What an SDS is and where to find them and other safety information?

Table 14. Observational checklist surveyed data of fume hood, chemical handling and storage

\begin{tabular}{|c|c|c|}
\hline Fume Hood and Chemical Handling (FHCH) & YES & NO \\
\hline Fume hood is functional & $18(64.3 \%)$ & $10(35.7 \%)$ \\
\hline Fume hood is not used as permanent storage for chemicals & $2(7.1 \%)$ & $26(92.9 \%)$ \\
\hline Chemical fume hood has been tested within last year & $18(64.3 \%)$ & $10(35.7 \%)$ \\
\hline Gas cylinders stored upright and secured from tipping with chains & $28(100 \%)$ & $0 \%$ \\
\hline Protective caps in place while cylinders are in storage & $28(100 \%)$ & $0 \%$ \\
\hline Shelving adequate for chemicals loads imposed with NFPA \& GHS & $18(64.3 \%)$ & $0 \%$ \\
\hline Chemical containers clearly labeled with contents & $19(67.9 \%)$ & $9(32.1 \%)$ \\
\hline Chemicals are segregated by hazards class such as flammable, corrosive and oxidizers etc. & $19(67.9 \%)$ & $9(32.1 \%)$ \\
\hline Chemical storage cabinets are labelled properly & $19(67.9 \%)$ & $9(32.1 \%)$ \\
\hline Corrosive chemical stored in acid cabinet & $3(10.7 \%)$ & $9(32.1 \%)$ \\
\hline Volatile chemicals are stored in unventilated locations labs. & $0 \%$ & $18(64.35)$ \\
\hline Flammable storage cabinets used for flammables storage. & $21(75.0 \%)$ & $7(25.0 \%)$ \\
\hline Formaldehyde and xylene are kept in safety cabinet & $21(75.0 \%)$ & $7(25.0 \%)$ \\
\hline
\end{tabular}


Almost $36 \%$ of the fume hoods in the labs were not functioning, with no previous maintenance records. All the gas cylinders were stored upright and secured from tipping with chains, and protective caps were in place while cylinders are in storage. Regarding chemical storage and chemicals labelling, the results showed some problems in this regard. Table 14.

This, however, can be resolved through the university's hospital laboratory training program and continual evaluation of laboratory staff accordingly. The training program can cover the following areas; laboratory orientation, what to do in the event of emergency, knowledge about SDS, use of appropriate PPE. Based on previous organizational and experience lab staffs were aware about the type of PPE use and precautions regarding most hazardous materials used in the lab. Overall, the average results of the occupational health and safety status was found to be $45 \%$ for all safety elements surveyed.

\section{Discussion}

Medical laboratories are considered potentially hazardous workplaces, workers in labs are exposed to a wide range of biologic hazards in addition to physical incidents. There is general agreement about adequate preparation of the workers in terms of training to improve their knowledge and skills in addition to providing them with proper personal protective equipment. Almost all measures and guidelines are listed in manuals which are distributed to labs workers, but the adherence to such measures, and acquired knowledge about biosafety, as another issue, which needs to be investigated, especially that faulty practices could cause serious health problems.

We set out this cross sectional survey study to assess the level of occupational safety practices among a specific category of health care workers who were laboratory staff, consequently the disparity in the age and gender and further disagrees with the outcomes on occupational health hazards study among health care workers who worked in 8 major health facilities in Kampala, Uganda, where results indicated male respondents were $28.5 \%$ while female respondents were $71.5 \%$ compared $68 \%$ males, and $32 \%$ females in our study ${ }^{(41) .}$ The status of occupational safety among health service providers in Tanzania indicated that majority of the respondents did not have post graduate degree training, and none had received training on Occupational Safety and Health as a profession ${ }^{(42) .}$ Additionally, in a similar study from Kenya reported that participants were mostly of Diploma level of education $(78.43 \%)^{(43)}$. Our results were comparable to these results since the largest proportion of the participants have either B.Sc., or master $\& \mathrm{PhD}$ as they know who to deal with occupational safety practices in laboratory, but they need continuous training.

The laboratory staff at work are constantly exposed to the danger of accidents if they are not handled properly and according to the regulations. Knowledge of equipment's use, safe environment and safety regulations is of high important enough, and it should be enough to change the attitude of the employees to carry out the task safely and effectively. ${ }^{(44)}$ The current study results showed high positive knowledge and attitude towards occupational safety practice in laboratory In an agreement with our results, a similar study ${ }^{(45)}$ reported high level of knowledge by Nigerian healthcare workers. Safety rules in laboratory should be practiced from time to time and it is the responsibility of the staff to avoid accidents from 
happening. Consequently, to prevent and reduce accidents risk, awareness of the importance of safety practices need to be well implemented and improved. Normally occurring accidents have relevance contributed by negligence, the lack of knowledge of any works to be carried out as well as damage or failure either on materials, equipment and chemical used ${ }^{(46,47)}$. The World Health Organization and other leading bodies recommend the importance of hand hygiene before donning nonsterile gloves, despite the lack of evidence for that. ${ }^{(18)}$ In this regard, similar study concluded that the utility of hand hygiene before donning nonsterile gloves may be unnecessary ${ }^{(48,49)}$. In our study, washing hands before putting on gloves was the lowest scored item, and more than half of the respondents disagree on it.

In an accordance with study from Malaysia, the current study showed significant associations between age group and the level of knowledge and practice of occupational safety in labs. Another study ${ }^{(49)}$, found that age group showed significant association with work related injuries (WRI), where younger aged group (18-44 years old) had higher occurrence of WRI compared to older age group.

In Nigeria, similar study ${ }^{(45)}$ found that job experience played a vital role in the knowledge and attitude of healthcare workers on laboratory hazard. This was in an agreement with our results

A study done on occupational injury showed significantly more WRI than females ${ }^{(49)}$ and similarly in a Malaysian study ${ }^{(50)}$, women have shown a better knowledge, attitude and practice on WRI and thus making them less prone to suffer from WRI. This was the with our findings, however the difference was statistically non-significant.

The observation checklist highlighted that there are some main points with problems in the labs included in the study, such problems need to be solved from responsible subjects and healthcare authorities. In a survey of safety practices among hospital laboratories in Ethiopia, it was found that although there were lists of chemical records in all laboratories assessed, all chemicals were not labeled with full chemical information and it is unknown who labels some of the chemicals ${ }^{(28)}$. in the current study, almost one thirds of the labs did not label chemicals properly.

A study from Kenya ${ }^{(31)}$ indicated that $94 \%$ of laboratories lacked hearing protective devices, and $60 \%$ did not wear any Personal Protective Equipment while in the medical laboratory. In Pakistan a study revealed that $46.2 \%$ of the laboratory technicians did not use any kind of personal protective equipment, ${ }^{(33)}$. Our results were near to that from Kenya, and far higher than that from Pakistan.

For achieving best practice, laboratories workers need to be empowered by proper enough training to improve their knowledge and skills, provide them with clear instructions with manuals, in addition to availing all personal protective equipment and ensuring safe work environment ${ }^{(51)}$. In contrast to the study from Kenya ${ }^{(31)}$.in which protective gloves were $100 \%$ provided in all the laboratories, more than $94 \%$ of the current study lab were not supplied with hand gloves.

Clinical laboratories are considered significant generators of infectious waste, including contaminated sharps, microbiological materials, and pathologic wastes such as blood 
specimens and blood products. ${ }^{(33)}$. The current study showed a good level of waste and hazardous waste management. A study of medical waste management involved 22 Brazilian clinical laboratories showed that hazardous wastes were segregated in $14 \%$ of the clinical assessed labs ${ }^{(51)}$. Our results were far better from this, since $100 \%$ of waste was segregated and stored appropriately away from drains. The current analysis of laboratory waste management processes indicates that the most problematic area was at container sealing stage.

A previous study from Jeddah, Saudi Arabia, reported that training on occupational health and safety were a significant predictor of knowledge of the health workers in the labs, and the findings of this study showed that there is a great need to establish health and safety program for laboratory safety officer, as well as the need to organize a national training programs to increase awareness of the Laboratories health workers about proper laboratory techniques and self-hygienic principles ${ }^{(27)}$. The current findings revealed that more than one third of the lab worked did not attend safety training or orientation programs. Another study from Al Madinah, Saudi Arabia, ${ }^{(35)}$ showed that a fraction of medical laboratory staff participated in the study had no previous training on lab safety, which is almost similar to ours, and this was associated with inappropriate behaviors like use of cosmetics, eating/drinking in the labs, and continue working with torn gloves and injured fingers. The percentage of those who did not receive training is considered low when compared to equivalent regional studies. For example, previous studies from Sudan and Pakistan reported that about $60-84.2 \%$ of the respondents did not have any training in biosafety ${ }^{(52)}$. In a study from Yemen, of the private and public laboratory staff, $67 \%$ and $32 \%$ had training in biosafety ${ }^{(53)}$.

As all other studies, this study had limitations. The investigation involved only one city in Saudi Arabia and even not all clinical laboratories there participated. Much of the data collected came from a self-reporting questionnaire, Therefore, the accuracy of the study results relied on the morality and perception of respondents in answering the addressed questionnaire. A comparison with other cities and clinical laboratories in Saudi Arabia was difficult because of a paucity of published studies.

\section{Conclusion}

Overall, there was a positive knowledge and attitude towards occupational safety practices among medical laboratory staff in governmental hospitals in Riyadh, Saudi Arabia. There was significant positive relationship between occupational safety practices and both nationality and age group.

The observation checklist revealed that almost most of the occupational safety subscales parameters were followed to a good extent in the assessed labs, with the exceptions of few parameters that need to be looked at, especially the in the use of PPE and electrical safety measures

Knowledge and attitude on occupational safety practices among laboratory staffs can be improved by organizing regular laboratory safety training. The importance and impact of good implementation of such occupational safety practices for the staff, the patients and even the country, should be emphasized. This will instill a safe work culture among laboratory 
workers and indirectly reduce the occurrence of work-related injuries.

Finally, it is worth to mention that the current study was a modest scale investigation that provided baseline data related to occupational safety measures of medical laboratories in Riyadh city. Therefore, large scale studies are needed at a national scale to define the rates of compliance and identify probable widespread health hazards to laboratory workers.

\section{References}

1. RHill, R. H. (2007). The emergence of laboratory safety. Journal of Chemical Health and Safety, 14(3), 14-19.

2. A study on knowledge, attitude and practice of laboratory safety measures among paramedical staff of laboratory services [Internet]. [cited 2019 Apr 5]. Available from: http://connection.ebscohost.com/c/articles/83290491/study-knowledge-attitude-practice-1 aboratory-safety-measures-among-paramedical-staff-laboratory-services

3. Chauhan, A., Anand, T., Kishore, J., Danielsen, T. E., \& Ingle, G. K. (2014). Occupational hazard exposure and general health profile of welders in rural Delhi. Indian Journal of Occupational and Environmental Medicine, 18(1), 21. https://doi.org/10.4103/0019-5278.134953

4. Hofmann, D. A., Burke, M. J., \& Zohar, D. (2017). 100 years of occupational safety research: From basic protections and work analysis to a multilevel view of workplace safety and risk. J Appl Psychol, 102(3), 375-388. https://doi.org/10.1037/apl0000114

5. Tompa, E., Kalcevich, C., Foley, M., McLeod, C., Hogg-Johnson, S., Cullen, K., et al. (2016). A systematic literature review of the effectiveness of occupational health and safety regulatory enforcement. Am $J$ Ind Med., 59(11), 919-933. https://doi.org/10.1002/ajim.22605

6. Valenti, A., Gagliardi, D., Fortuna, G., \& Iavicoli, S. (2016). Towards a greener labour market: occupational health and safety implications. Ann Ist Super Sanita, 52(3), 415-423. https://doi.org/10.4415/ANN_16_03_13.

7. Nisii, C., Castilletti, C., Di Caro, A., Capobianchi, M. R., Brown, D., Lloyd, G., et al. (2009). The European network of Biosafety-Level-4 laboratories: Enhancing European preparedness for new health threats. ClinMicrobiol Infect, 15(8), 720-26. https://doi.org/10.1111/j.1469-0691.2009.02946.x.

8. Tohda, S. (2016). Infection Control from the Viewpoint of Medical Safety by Our Clinical Laboratory in TMDU Hospital. RinshoByori, 64(3), 334-337.

9. Auta, A., Adewuyi, E. O., Tor-Anyiin, A., Aziz, D., Ogbole, E., Ogbonna, B. O., et al. (2017). Health-care workers' occupational exposures to body fluids in 21 countries in Africa: systematic review and meta-analysis. Bull World Health Organ, 95(12), 831-841. https://doi.org/10.2471/BLT.17.195735

10. De Carli, G., Abiteboul, D., \& Puro, V. (2014). The importance of implementing safe sharps practices in the laboratory setting in Europe. Biochem Med (Zagreb), 24(1), 45-56. https://doi.org/10.11613/BM.2014.007. 
11. Baussano, I., Nunn, P., Williams, B., Pivetta, E., Bugiani, M., \& Scano, F. (2011). Tuberculosis among Health Care Workers. Emerg Infect Dis, 17(3), 488-494. https://doi.org/10.3201/eid1703.100947.

12. Nasreen, S., Shokoohi, M., Malvankar-Mehta, M. S. (2016). Prevalence of Latent Tuberculosis among Health Care Workers in High Burden Countries: A Systematic Review and Meta-Analysis. PLoS ONE, 11(10), e0164034. https://doi.org/10.1371/journal.pone.0164034

13. Balkhiour, M. A. (2011). Evaluation of the Safety Status in Some University Laboratories. Journal of King Abdulaziz University: Meteorology, Environment \& Arid Land Agriculture Sciences, 22(1).

14. Shnawa, Z. K. (2017). Chemical Safety in Chemistry Departments Laboratories at Iraqi Universities. Iraqi National Journal of Chemistry, 17(2), 149-156.

15. Reddy, S., Sadhan, D., Doshi, D., Kulkarni, S., Srikanth Reddy, B., \& Padma Reddy, M. (2017). Occupational Hazards in Dentistry, 6, 110.

16. Manyele, S. V., Ngonyani, H. a. M., \& Eliakimu, E. (2008). The status of occupational safety among health service providers in hospitals in Tanzania. Tanzan J Health Res., 10(3), 159-165.

17. Khasawne, A. (2014). Improving occupational health and workplace safety in Saudi Arabia. International Journal of Development and Sustainability, 3(2), 261-267.

18. Chelenyane, M., \& Endacott, R. (2006). Self-reported infection control practices and perceptions of HIV/AIDS risk amongst emergency department nurses in Botswana. AccidEmergNurs, 14(3), 148-154. https://doi.org/10.1016/j.aaen.2006.03.002

19. Shariff, A. M., \& Norazahar, N. (2012). At-risk behaviour analysis and improvement study in an academic laboratory. Safety Science, 50(1), 29-38. https://doi.org/10.1016/j.ssci.2011.06.008

20. Kimman, T. G., Smit, E., \& Klein, M. R. (2008). Evidence-based biosafety: a review of the principles and effectiveness of microbiological containment measures. ClinMicrobiolRev., 21(3), 403-425. https://doi.org/10.1128/CMR.00014-08

21. Marinucci, F., Majigo, M., Wattleworth, M., Paterniti, A. D., Hossain, M. B., \& Refield, R. (2013). Factors affecting job satisfaction and retention of medical laboratory professionals in seven countries of sub-Saharan Africa. Hum Resour Health, 11(38), 1-7. https://doi.org/10.1186/1478-4491-11-38.

22. Fadaei, N., Zainuddin, H., Tajuddin, S., \& Stajuddinsyed, H. (2014). Job Dissatisfaction and Its Related Factors among Laboratory Staff, 43, 142.

23. Vonesch, N., Tomao, P., Di Renzi, S., Vita, S., \& Signorini, S. (2006). Biosafety in laboratories concerning exposure to biological agents. G Ital Med LavErgon, 28(4), 444-456. 
24. Javed Akhter Sameera Al Johani, Loulwah Hammad, \& Khalid Al Zahrani. (2011). Laboratory Work Practices and Occupational Hazards among Laboratory Health Care Workers: A Health and Safety Survey. J Pharm Biomed Sci., 4, 9.

25. Nasim, S., Shahid, A., Mustufa, M. A., Arain, G. M., Ali, G., Taseer, I.-H. et al. (2012). Biosafety perspective of clinical laboratory workers: a profile of Pakistan. $J$ Infect DevCtries, 6(8), 611-619. https://doi.org/10.3855/jidc.2236.

26. Cruz, C. P., Cruz, J. P., Abu Bakr, S. A., \& Thazha, S. K. (2015). Biosafety knowledge and perceptions of clinical laboratory science educators in Shaqra University. $J$ Infect Public Health, 8(4), 398.

27. Al-Zahrani, K. (2018). Assessment of Biosafety and associated Occupational Hazards among Laboratories Health Workers in Governmental Moderate and High Complexity Medical Labs. Journal of Medical Science and Clinical Research, 2(6).

28. Sewunet, T., Kebede, W., Wondafrash, B., Workalemau, B., \& Abebe, G. (2014). Survey of Safety Practices Among Hospital Laboratories in Oromia Regional State, Ethiopia. Ethiop J Health Sci., 24(4), 307-310.

29. Shobowale, E., Elikwu, C. J., Coker, A. O., Mutiu, P. B., Nwadike, V. et al. (2015) A Survey of Biosafety Practices of Clinical LaboratoryPersonnel in Four Selected Clinical Laboratories. Med Safe Glo Heal, 4, 123. https://doi.org/10.4172/2574-0407/1000123

30. Abbas, M., Zakaria, A. M., Balkhyour, M. A. (2016).Investigation of safety facilities and safe practices in chemical laboratories of a Saudi university. Journal of Environment and Safety, 7(2), 141-147. https://doi.org/daikankyo.E15RP1001

31. Tait, F. N., Mburu, C., \& Gikunju, J. (2018). Occupational safety and health status of medical laboratories in Kajiado County, Kenya. The Pan African Medical Journal, 29, 65. https://doi.org/10.11604/pamj.2018.29.65.12578

32. Elduma, A. H. (2012). Assessment of biosafety precautions in Khartoum state diagnostic laboratories, Sudan. Pan Afr Med J [Internet]. 2012 Feb 3 [cited 2019 Apr 6];11. Available from: https://www.ncbi.nlm.nih.gov/pmc/articles/PMC3325057/

33. Nasim, S., Shahid, A., Mustufa, M. A., Arain, G. M., Ali, G., Taseer, I.-H. et al. (2012). Biosafety perspective of clinical laboratory workers: a profile of Pakistan. $J$ Infect DevCtries, 6(8), 611-619. https://doi.org/10.3855/jidc.2236

34. Qasmi, S. A., Khan, E., \& Maqbool, A. Z. (2012). Survey of Biorisk Management in Clinical Laboratories in Karachi, Pakistan. Appl Biosaf, 17(4), 198-207. https://doi.org/10.1177/153567601201700405

35. Khabour, O. F., Ali, K. H. A., Aljuhani, J. N., Alrashedi, M. A., Alharbe, F. H., \& Sanyowr, A. (2018). Assessment of biosafety measures in clinical laboratories of Al-Madinah city, Saudi Arabia. 12(9), 755-761. https://doi.org/10.3855/jidc.10081

36. Galarpe, V. R. K., C. Lamela, N., \& Alcantara, R. (2013). Preliminary evaluation of laboratory practices in Cebu Doctors'University, Philippines, 20, 25-30. 
37. Walters, A. U. C., Lawrence, W., \& Jalsa, N. K. (2017). Chemical laboratory safety awareness, attitudes and practices of tertiary students. Safety Science, 1(96), 161-171. https://doi.org/10.1016/j.ssci.2017.03.017

38. da Costa, E. D., Pinelli, C., da Silva Tagliaferro, E. P., Corrente, J. E., Ambrosano, G. M. B. (2017). Development and validation of a questionnaire to evaluate infection control in oral radiology. Dentomaxillofac Radiol, 46(4), 20160338. https://doi.org/10.1259/dmfr.20160338.

39. European Agency for Safety \& Health at Work - Information, statistics, legislation and risk assessment tools. [Internet]. [cited 2019 Apr 5]. Available from: https://osha.europa.eu/en

40. Prudent Practices in the Laboratory: Handling and Management of Chemical Hazards, Updated Version | The National Academies Press [Internet]. [cited 2019 Apr 5]. Available from: https://www.nap.edu/catalog/12654/prudent-practices-in-the-laboratory-handlingand-management-of-chemical.

41. Ndejjo, R., Musinguzi, G., Yu, X., Buregyeya, E., Musoke, D., Wang, J.-S. et al. (2015). Occupational Health Hazards among Healthcare Workers in Kampala, Uganda [Internet]. Journal of Environmental and Public Health. https://doi.org/10.1155/2015/913741

42. Manyele, S. V., Ngonyani, H. A., \& Eliakimu, E. (2008). The status of occupational safety among health service providers in hospitals in Tanzania. Tanzan J Health Res., 10(3), 159-165.

43. Misra, U. B., Agawu, K., Parmar, N. K., \& Bhahrar, R. (2001). An Epidemiologic Study of Biohazard in a Microbiology Laboratory at a Large Teaching Hospital. J of Academic Hospital Administration, 12, 12.

44. Hassan, N. H. C., Ismail, A. R., Makhtar, N. K., Sulaiman, M. A., \& Subki, N. S. Hamzah, N. A. (2017). Safety and health practice among laboratory staff in Malaysian education sector. IOP ConfSer: Mater Sci Eng., 257, 012004. https://doi.org/10.1088/1757-899X/257/1/012004

45. Aluko, O. O., Adebayo, A. E., Adebisi, T. F., Ewegbemi, M. K., Abidoye, A. T., \& Popoola, B. F. (2016). Knowledge, attitudes and perceptions of occupational hazards and safety practices in Nigerian healthcare workers. BMC Res Notes BMC Res Notes, 9, 71 https://doi.org/10.1186/s13104-016-1880-2.

46. Ford, M. T., \& Tetrick, L. E. (2011). Relations among occupational hazards, attitudes, and safety performance. J Occup Health Psychol, 16(1), 48-66. https://doi.org/10.1037/a0021296.

47. Smith, T. D., \& DeJoy, D. M. (2012). Occupational injury in America: An analysis of risk factors using data from the General Social Survey (GSS). J Safety Res, 43(1), 67-74. https://doi.org/10.1016/j.jsr.2011.12.002.

48. Rock, C., Harris, A. D., Reich, N. G., Johnson, J. K., \& Thom, K. A. (2013). Is hand hygiene before putting on nonsterile gloves in the intensive care unit a waste of health 
care worker time? - A randomized controlled trial. American journal of infection control, 41(11), 994. https://doi.org/10.1016/j.ajic.2013.04.007

49. Main, C. L., Carusone, S. C., Davis, K., \& Loeb, M. (2008). Compliance with personal precautions against exposure to bloodborne pathogens among laboratory workers: a Canadian survey. Infect Control Hosp Epidemiol, 29(1), 66-68. https://doi.org/10.1086/524325

50. Netto, E. F., \& Rahmawati, T. (2017). Predictors of knowledge, attitude and practices on work related injuries among laboratory staffs in a public university in Malaysia. International Journal of Public Health and Clinical Sciences, 4(5), 139-157.

51. Da Silva, C. E., Hoppe, A. E., Ravanello, M. M., \& Mello, N. (2005). Medical wastes management in the south of Brazil. Waste Manag., 25(6), 600-605. https://doi.org/10.1016/j.wasman.2004.03.002

52. Elduma, A. H., \& Saeed, N. S. (2011) Hepatitis B virus infection among staff in three hospitals in Khartoum, Sudan, 2006-07. East Mediterr Health J., 17, 474-478.

53. Al-Abhar, N., Al-Gunaid, E., Mogram, G., Al-Habibi, A. A., Alserouri, A., \& Khader, Y. (2017). Knowledge and practice of biosafety among laboratory staff working in clinical laboratories in Yemen. ApplBiosaf, $22, \quad$ 168-171. https://doi.org/10.1177/1535676017733451

\section{Copyright Disclaimer}

Copyright for this article is retained by the author(s), with first publication rights granted to the journal.

This is an open-access article distributed under the terms and conditions of the Creative Commons Attribution license (http://creativecommons.org/licenses/by/4.0/) 